\title{
Ficus religiosa Tree Leaves as Bioindicators of Heavy Metals in Gorakhpur City, Uttar Pradesh, India
}

\author{
Pooja Agrahari ${ }^{1}$, Richa ${ }^{2}$, Kumari Swati ${ }^{2}$, Supriya Rai ${ }^{2}$, Vinay Kumar Singh ${ }^{1}$, Dinesh Kumar Singh ${ }^{1 *}$
}

Pooja Agrahari' ${ }^{1}$ Richa², Kumari Swati², Supriya Rai $^{2}$, Vinay Kumar Singh', Dinesh Kumar Singh ${ }^{1 *}$

'Malacology Laboratory, Department of Zoology, D.D.U. Gorakhpur University, Gorakhpur, Uttar Pradesh, INDIA.

${ }^{2}$ M.Sc Students (2016)-Department of Environmental Science, D.D.U. Gorakhpur University, Gorakhpur, Uttar Pradesh, INDIA.

\section{Correspondence}

Dinesh Kumar Singh

Department of Zoology Malacology Laboratory, D.D.U. Gorakhpur University, Gorakhpur, Uttar Pradesh-273009, INDIA.

Phone No: +91-551-2202187

E-mail: dksingh_gpu@yahoo.co.in

History

- Submission Date: 29-08-2017.

- Review completed: 15-09-2017;

- Accepted Date: 20-11-2017

DOI : $10.5530 / p j .2018 .3 .68$

Article Available online

http://www.phcogj.com/v10/i3

\section{Copyright}

(c) 2018 Phcog.Net. This is an openaccess article distributed under the terms of the Creative Commons Attribution 4.0 International license.

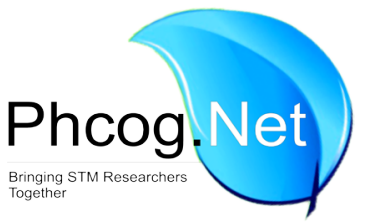

\begin{abstract}
Objective: The present work investigates the metal uptake of the plant Ficus religiosa leaves collected from nine experimental sites in Gorakhpur, Uttar Pradesh. Materials and Methods: The concentration of lead in leaves was determined with help of atomic absorption spectrophotometer. Results: The level of the lead in leaves of Ficus religiosa was much higher than the limits recommended by World Health Organization (WHO). The bioaccumulation of lead was highest in site 2 (Gayatri nagar) i.e. $14.1 \mathrm{mg} \mathrm{kg}^{-1}$ dry weight of $F$. religiosa. To determine the relationship between the lead concentration in leaves and traffic density the Pearson's correlation analysis has been performed. Conclusion: The value of Pearson's correlation coefficient $(r)$ was positive indicating that the traffic density plays an important role in the lead pollution in plants.

Key words: Metal, Lead, Atomic absorption spectroscopy.
\end{abstract}

\section{INTRODUCTION}

The high concentration of heavy metals in plants is reflected by higher concentrations of metals in the atmosphere, and consequently in animal and human bodies. The ability of some plants to absorb and accumulate xenobiotics makes them useful as indicators of environmental pollution. Heavy metals can be a major problem for any biological organism as they may be reactive with many chemicals essential to biological processes. A higher level of lead in roadside environment is often associated with the traffic density. ${ }^{1,2,3}$ Vehicular emissions along the busy roadways contain high levels of lead, which are present in fuel as anti-knock agents. ${ }^{4,5}$ The automobiles are extensively used petrol in India. The smoke releases the metallic oxides particularly $\mathrm{PbO}_{2}$ and dust. Although, use of leaded gasoline has decreased in various countries of the world but increase in automobile numbers compensated its effect on vehicles based $\mathrm{Pb}^{2+}$ emission. In developing countries an estimated 0.5-1.0 million peoples die prematurely each year because of exposure to urban air pollution. ${ }^{6}$

Several researchers designated heavy metals $(\mathrm{Pb}, \mathrm{Cu}$, $\mathrm{Ni}, \mathrm{Cr}$, and $\mathrm{Cd}$ ) as priority pollutants and had identified 16 different PAH "priority pollutants" which have stronger toxicity than others have and can be absorbed by the leaves of plants. ${ }^{7,89}$ Several researchers have been exploring contaminant uptake by plants and its mechanisms. It could be used to optimize the factors to improve the performance of plant uptake. According to Sinha et al. ${ }^{10}$ the plants act both as "accumulators" and as "excluders." Accumulators survive despite concentrating contaminants in their aerial tissues. They biodegrade or biotrans form the contaminants into inert forms in their tissues. The excluders restrict contaminant uptake into their biomass.

Today, Indian cities are considered as most polluted in the world and the single most important factor responsible is the ever-increasing number of automobiles. This fact is also true for the city (Gorakhpur), where there are already more than seven lacks motor vehicles. The ever-increasing vehicular traffic density posed continued threat to the ambient air quality. There are more petrol driven vehicles in Gorakhpur. Bioindicators provide a practical way of assessing the health of environment. Biological indicators have been used for many years to detect the deposition, accumulation and distribution of heavy metal pollution. Various groups of higher plants serve as bioindicators. Different species have been used to detect and monitor gaseous as sulphur dioxide, nitrous oxide and ozone as well as heavy metal pollutants. Ficus species have wide distribution and uses worldwide traditionally as medicine, vegetable, food, fodder, and fuel wood etc. World Health Organization (WHO) has recommend that medicinal plants which form the raw materials for the finished products may be checked for the presence of heavy metals, further it regulates maximum permissible limits of toxic metals like arsenic, cadmium and lead. ${ }^{11}$

The aim of the present study was to indicate the status of lead in tree leaves from the residential
Cite this article: Agrahari P, Richa, Swati K, Rai S, Singh VK, Singh DK. Ficus religiosaTree Leaves as Bioindicators of Heavy Metals in Gorakhpur City, Uttar Pradesh, India. Pharmacog J. 2018;10(3):416-20. 
areas, heavy traffic affected areas, highways and roadside areas of Gorakhpur city in Uttar Pradesh.

\section{MATERIALS AND METHODS}

\section{Sampling sites}

Various sites i.e., residential areas, heavy traffic areas, highways and roadside areas were selected for collection of leaves (Ficus religiosa). Three factors were considered during site selection: industrialization, main city road and residential areas. All these sites were situated in Gorakhpur (Latitude $26^{\circ} 46^{\prime} \mathrm{N}$, Longitude $83^{\circ} 22^{\prime}$ E) district of Uttar Pradesh, India. Gorakhpur is an industrialized city, heavy a population of more than 50 lakh in $7483.8 \mathrm{~km}$ square area. A schematic representation of sampling sites has been described in Figure 1.

\section{Sample Description}

"Ficus religiosa or sacred fig is a species of fig native to Nepal, India, Bangladesh, Myanmar, Pakistan, Sri Lanka, south-west China and Indochina. It belongs to the Moraceae, the fig or mulberry family. We have chosen Ficus tree leaves due to its morphology, its broad leaf structure, rough surface and long drip tips. These drip tips help the leaves dry after it rains hence it collects dust and pollution more rapidly. The leaves of this tree move continuously even when the air is still, and no perceptible wind is blowing. This phenomenon can be explained due to the long leaf stalk and the broad leaf structure. So that Ficus religiosa leaves is appropriate as bioindicator of air pollution. We took the roadside samples for the detection of lead.

\section{Sampling procedure}

Nine sites were selected in the city Gorakhpur and the surrounding. Leaves were sampled from one type of tree i.e Peepal (Ficus religiosa) before fall. After rainy season, when leaves were washed with water, many leaves were marked (at a height of about $1.5-2.0 \mathrm{~m}$ above the ground) for experimental observation in different sites. After 3 months, these leaves were collected uniformly from the trees. After drying at $60^{\circ} \mathrm{C}$ and pulverizing, the leaves were placed in polythene containers and stored in the refrigerator.

\section{Chemicals Used}

Nitric acid $\left(\mathrm{HNO}_{3}\right)$ (Merck, pro analysi) and Millipore water. Standard of $\mathrm{Pb}$ was purchased from Perkin Elmer, 710 Bridgeport Avenue (USA).

\section{Analytical Methods}

The wet digestion of organic matrix samples by the use of concentrated $\mathrm{HNO}_{3}$ is the most common procedure. The digestion time was extended so as to achieve maximum recoveries of metal in the solution.

About $1 \mathrm{~g}$ dried wet of each sample was placed in an open quartz tube. $8 \mathrm{ml}$ of concentrated $\mathrm{HNO}_{3}$ were added to each tube and the mixture was left at room temperature overnight. It was warmed for $2 \mathrm{~h}$ at $50^{\circ} \mathrm{C}$ and heated at $180^{\circ} \mathrm{C}$ for $4 \mathrm{~h}$. The Solution was filtered through Whatman type 589/2 filter paper and the filtrate was diluted to $25 \mathrm{ml}$ volume with double deionized water. Each final solution was analyzed for lead $(\mathrm{Pb})$ concentration. After the analysis the concentration of lead $(\mathrm{Pb})$ in leaves collected from the 9 sites were compared to the reference.

A Perkin Elmer Atomic absorption spectrometer A Analyst 400 was used, coupled with graphite furnace controller. Graphite furnace technique was used for the analysis of $\mathrm{Pb}$. The analytical wavelength was at 283.31 for $\mathrm{Pb}$. At least five standard solutions were prepared for metal detection. Each measurement was replicated six times.

\section{RESULTS}

The mean concentration of lead of the trees leaves Ficus religiosa from each site is shown in Figure 2. The bioaccumulation of lead was higher in site 2 (Gayatri nagar) i.e. $14.1 \mathrm{mg} \mathrm{kg}^{-1}$ dry weight, slightly lower in Site 1 (Mohaddipur) i.e., $11.6 \mathrm{mg} \mathrm{kg}^{-1}$ dry weight. It was observed to be lowest in Site 6 (GIDA) i.e., $2.9 \mathrm{mg} \mathrm{kg}^{-1}$ dry weight and Site 3 (Nandanagar) i.e., $2.5 \mathrm{mg} \mathrm{kg}^{-1}$ dry weight depending upon the traffic conditions of the site selected. This indicates significant lead accumulation in plants growing along the roadside. The concentration of metal was expressed as the mean value from analysis of the specimens collected before the fall, as described in the material and method section.

According to $\mathrm{WHO}$, the normal $\mathrm{Pb}$ range for air is $2 \mathrm{mg} \mathrm{kg}^{-1}$ dry weight Figure 2. The lead concentrations from all sites were highly above from the WHO standard. Figure 3 shows the traffic density/hr. A significant

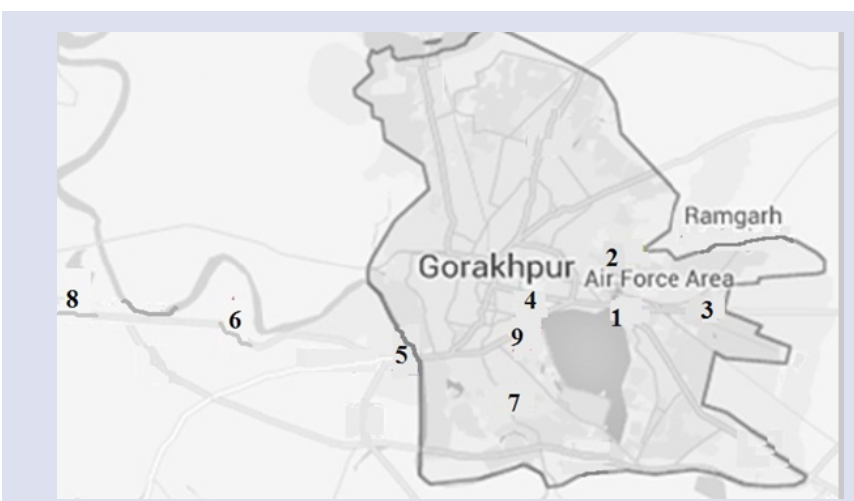

Figure 1: Schematic representation of various sampling sites from Gorakhpur city. The numbers refer to the following sampling sites: (1) Mohaddipur, (2) Gaytrinagar, (3) Nandanagar, (4) RTO, (5) Nausadh, (6) GIDA, (7) Taramandal, (8) Sahjanwa, (9) University campus.

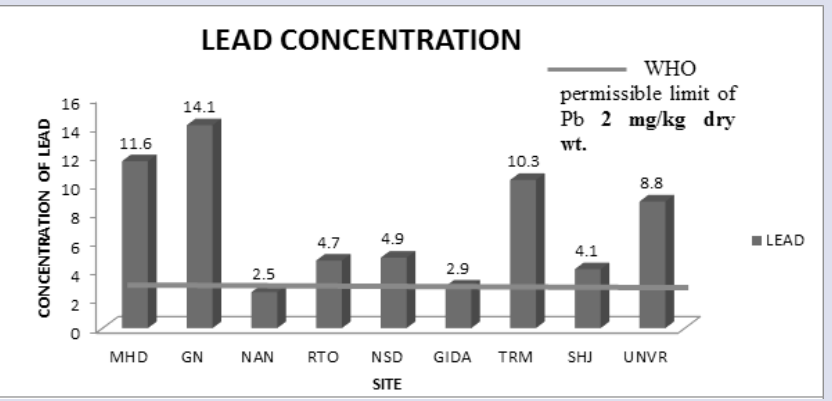

Figure 2: Graph showing lead concentration in various sampling sites. A cross line indicate the WHO level of lead concentration.

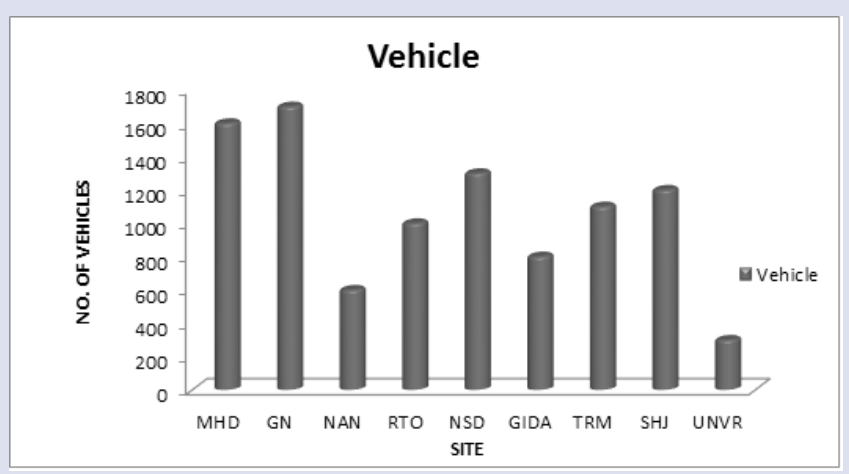

Figure 3: Graph showing the no. of vehicles or traffic density/ hours in various sampling sites. 
$(P<0.05)$ positive correlation was shown between lead concentration and traffic density $(\mathrm{r}=0.536)$.

\section{DISCUSSION}

Heavy metal pollution represents an important environmental problem due to toxic effect of metals, and their accumulation throughout the food chain leading to serious ecological and health problems. Lead is deposited in bone as a cumulative poison; most of the lead intake by a typical city dweller is from diet (200-300 micro g per day); air and water further add 10-15 micro g per day each. ${ }^{12}$ A million ton of lead is deposit into the environment during, mining and from automobiles. Lead pollution on a local scale is caused by emissions from vehicles using leaded gasoline..$^{13}$ Lead is transported by blood within the body. It is stored in teeth, bones and soft tissues including brain. Normal and safe level of lead in blood is 0.2 ppm. ${ }^{14}$ Symptoms of lead poisoning are numerous, Plumbism a disease caused by acute lead poisoning has been known for the century. Lead exposures have developmental and neurobehavioral effects on foetus, infants and children, and elevate blood pressure in adults. ${ }^{15}$ Nirmal et $a l^{16}$ emphasized that most of the accumulated lead is sequestered in the bones and teeth. This causes brittle bones and weakness in the wrists and fingers.

The relationship between lead concentrations and traffic intensity has been demonstrated in detail by many workers. ${ }^{17,18,19}$ In general, $\mathrm{Pb}$ concentrations in vegetation grown in industrial and urban areas have increased in recent decades owing to human activities and road traffic. According to our results, lead pollution was found in all sites. Analysis of $\mathrm{Pb}$ in Ficus leaves samples collected from all roadsides had shown that concentration of $\mathrm{Pb}$ was significantly above from the $\mathrm{WHO}^{20}$ permissible limit. Lead concentration in all samples ranges from $2.5-14.1 \mathrm{mg} / \mathrm{kg}$ dry weight, whereas WHO save limit of $\mathrm{Pb}$ is $2 \mathrm{mg} / \mathrm{kg}$ dry weight (2 ppm). ${ }^{20}$ Gayatri nagar (14.1 mg kg-1 dry weight) and Mohaddipur (11.6 mg kg-1 dry weight) had shown highest mean concentration of $\mathrm{Pb}$ in leaves samples Figure 2 that could be attributed to the fact that these are a mid-city road and links main areas of the city which led to continuous heavy flow of traffic mainly consisting of cars and bikes. Kruger $^{21}$ conducted a study in the city of Cape Town and found higher concentration of $\mathrm{Pb}(226.77 \pm$ $60.11 \mathrm{mg} / \mathrm{kg}$ ) at site where road was moving uphill and caused traffic to get slow and in return released more $\mathrm{Pb}$ from the exhaust. The standards set a permissible exposure limit (PEL) of fifty micrograms of lead per cubic meter of air $\left(50 \mathrm{ug} / \mathrm{m}^{3}\right)$, averaged over an 8-h work-day.

The highest value of lead was observed in Gayatrinagar is mainly because of the un-serviced vehicles i.e., tractors and trucks that continuously pass through that area. Since it is a residential area, such higher concentration can cause many serious health problems. Mohaddipur is also a highly traffic area and also the national highway passes through it, thousands of vehicles including cars, bikes, trucks, tractors etc continuously passes through this area, which are responsible for higher lead pollution. In 1959, Horiuchi et al. ${ }^{22}$ reported that the lead in the air over the main streets in Osaka City was higher than that found over open lots in factory (non-lead) districts or residential area. This investigation reported finding the highest concentrations over streets supporting dense traffic. Tara Mandal area of Gorakhpur city is a very busy road and approximately 1100 vehicles pass in a single $h$, so the concentration of lead is high (10.3 mg/kg dry weight). The location of University is in the mid of Gorakhpur city. The busiest routes also surround it. There is continuous passage of cars and bikes inside $(300 / \mathrm{hr})$ and outside $(1100 / \mathrm{hr})$ of the campus, so this may be the reason for the high value $\mathrm{Pb}$ concentration in University campus $\left(8.8 \mathrm{mg} / \mathrm{Kg}\right.$ dry weight). Rose et al. ${ }^{23}$ suggested that the high $\mathrm{Pb}$ value in plants were due to the uptake from the available $\mathrm{Pb}$ in the soil and in the above ground parts (leaves, stem and seeds) is due to air born $\mathrm{Pb}$.
Nausadh and Sahjanwa area also comes under a crowded area. Thousands of auto rickshaws, buses, and heavy vehicles like trucks passes by and nearly 25,000 to 30,000 vehicles pass in a single day through Sahjanwa itself. However, the concentration of $\mathrm{Pb}$ was less as compare to Gayatri Nagar and Mohaddipur, is because of Nausadh and Sahjanwa are an open area. The lead release from the vehicles was absorbed into the atmosphere.

The Regional Transport Office (RTO) area of Gorakhpur is in the city area and the routes connecting to city passes by this area. The leaves collected from GIDA shows a slightly less concentration as compared to the above-mentioned sites because there is less number of inhabitants in this region and the routes have lesser number of vehicles passing through the area as compared to the other sites. The Nanda nagar area is located nearer to the Kushmi forest and Ramgarh Lake so the local winds may be responsible for the lower concentration. Less concentrations of lead in this sight might be because Nanda Nagar Colony is a residential area and has a restricted traffic due to air force station. Olukanni and Adebiyi ${ }^{24}$ reported similar results in Nigeria where they found lower concentration $(0.11 \mathrm{mg} / \mathrm{kg})$ of $\mathrm{Pb}$ at site coded as $\mathrm{G}$ because of the least volume of vehicles recorded on that site. A significant positive correlation was found between lead concentration and traffic density indicates that traffic is very much responsible for lead concentration.

Metal pollution has a harmful effect on biological systems and does not undergo biodegradation. ${ }^{25}$ In the environment, lead is known to be toxic to plants, animals, and microorganisms. $\mathrm{Pb}$ contamination in the environment exists as an insoluble form, and the toxic metals pose serious human health problem, namely, brain damage and retardation. ${ }^{26}$ Lead that is stored in bones can re-enter the blood stream during periods of increased bone mineral recycling (pregnancy, lactation, menopause, advancing age, etc). Mobilized lead can be re-deposited in the soft tissues of the body and can cause musculoskeletal, renal, ocular, immunological, neurological, reproductive, and developmental effects. ${ }^{27}$

\section{CONCLUSION}

This study conclusively shows that the leaves of Ficus can be used as suitable bio-indicators for air pollution with $\mathrm{Pb}$. It can be used to monitor and ameliorate heavy metal pollution in the urban localities. Concentrations of lead in Ficus leaves across the polluted sites remained significantly higher. The positive correlation between lead concentration and traffic density indicate that automobiles are the main source of lead pollution in plants. Preventive measures are taken on time so that lead induced poisoning can be reduced, in fact the release of lead will be reduced, and it is essential too because over the coming years the use of vehicles will increase day by day. Lead Replacement Petrol (LRP) is a fuel developed to provide an alternative to leaded petrol. It can be concluded that use of lead free products and the unleaded petrol in vehicles is very important to check lead pollution. Therefore, prevention must be taken to reduce the harmful effects of pollution.

\section{Authors Contributions}

PA: Conception and Design; DKS: Development of Methodology; R, KS and SR: Acquisition of Data; PA, VKS and DKS: Analysis and Interpretation of Data; PA, VKS and DKS: Writing, review and revision of the manuscript; Administrative, technical or material support; DKS: Study Supervision; All authors are involved in drafting the manuscript, read and approved the final version of the manuscript.

\section{ACKNOWLEDGEMENT}

The authors are grateful to Head, Department of Zoology, D.D.U. Gorakhpur University, Gorakhpur for providing all necessary facilities to complete this work. 


\section{CONFLICT OF INTEREST}

We declare that we have no conflict of interest.

\section{ABBREVIATIONS USED}

MHD: Mohaddipur; GN: Gaytrinagar; NAN: Nandanagar; RTO: NSDNausadh; GIDA, TRM: Taramandal; SHJ: Sahjanwa; UNVR: University campus.

\section{REFERENCES}

1. Fergusson JE, Hayes RW, Young TS, Thiew SH. Heavy metal pollution by traffic in Christchurch, New Zealand, lead and cadmium content of dust, soil and plant samples. New Zeal J Sci. 1980;23:293-310.

2. Kartal S, Elci L, Dogan M. Investigation of lead, nickel, cadmium and zinc pollution of traffic in Kayseri. Fresen Environ Bull. 1992;1(1):28-33.

3. Arslan H. Heavy metals in street dust in Bursa, Turkey. J Trace Microprobe Tech. 2001:19(3):439-45.

4. Suzuki K, Yabuki T, Ono Y. Roadside Rhododendron pulchrum leaves as bioindicators of heavy metal pollution in traffic areas of Okayama, Japan. Environ Monitor Assess. 2009;149(1-4):133-41.

5. Atayese MO, Eigbadon Al, Oluwa KA, Adesodun JK. Heavy metal contamination of Amaranthus grown along major highways in Lagos. Afr Crop Sci J. 2008;16(4):225-35

6. Kojima ML. Urban air quality management. World Bank, Washington D.C. 2001.

7. Masitah A, Zaini H, Lee SK. PM10 and total suspended particulates (TSP) measurements in various power stations. Malays J Anal Sci. 2007;11(1):255-61

8. Yongzhen L, Guoxiang C, Hairuo Q, Tagen D, Qianhong W. Sources of polycyclic aromatic hydrocarbons in street dust from the Chang-Zhu-Tan region, Hunan, China. J Environ Prot. 2011;2(10):1331-40.

9. Al-Saadi GM. Assessment of air and water pollution due to operation south of Baghdad power plant. M.Sc. Thesis, Building and Construction Engineering Department University of Technology. 2012;147.

10. Sinha RK, Herat S, Tandon PK. Phytoremediation: role of plants in contaminated site management. Book of Environmental Bioremediation Technologies. Springer, Berlin, Germany. 2007;315-30.

11. World Health Organization. Quality Control Methods for Medicinal Plant Materials, WHO Geneva Switzerland. 1998.

12. Tiwari S, Tripathi IP, Tiwari HL. Blood Lead Level -A Review. Int J Scientific Eng Technol. 2014;3(4):330-3

13. Koepp DE. Lead: understanding the minimal toxicity of lead in plants. In: LEPP NW. (Ed.), Effect of heavy metal pollution on plants. Effects of trace metals on plant function. Applied Science Publishers, London. 1981;55-76.
14. Sharma BK. Environmental Chemistry. Goel Publishing House, a unit of Krishna Prakashan Media (P) Ltd, Meerut, Delhi. 2007.

15. Kosnett MJ. Health effects of low dose lead exposure in adults and children, and preventable risk posed by the consumption of game meat harvested with lead ammunition. In: Watson RT, Fuller M, Pokras M, Hunt WG. (Eds.). Ingestion of Lead from Spent Ammunition: Implications for Wildlife and Humans. The Peregrine Fund, Boise, Idaho, USA. 2009:24-33. DOI 10.4080/ilsa.2009.0103

16. Nirmal JIK, Soni H, Kumar RN. Characterization of heavy metals in vegetables using inductive coupled plasma analyzer (ICPA). J Appl Sci Environ Manag. 2007;11(3):75-9

17. Nwaedozie JM. The determination of heavy metal pollution in fish samples from River Kaduna. J Chem Soc Nigeria. 1998;23:21-3

18. Gromow S, Emelina E. Lead emission evaluation over the European part of the former Soviet Union. The Sci Tot Environ. 1994;158:135-7.

19. Li XC, Poon PL. Heavy metal contamination of urban soils and street dusts in Hong Kong. Appl Geochem. 2001;16(11):1361-8.

20. World Health Organization (WHO). Quality directive of potable water 2 nd ed Geneva: World Health Organization. 1994.

21. Kruger AL. Accumulation and Toxicity of Lead in Soil along the Road Verges in the City of Cape Town. M-Tech thesis, Environmental Health in the Faculty of Applied Sciences, Cape Peninsula University of Technology. 2007;18-102.

22. Horiuchi K, Horiguchi S, Suekane M. Studies on the industrial lead poisoning. 1: Absorption, transportation, deposition and excretion of lead. 6: The lead contents in organ-tissues of the normal Japanese. Osaka City Med J. 1959;5(1):41-70.

23. Rose M, Knaggs M, Owen L, Baxter M. A review of analytical methods for lead, cadmium, mercury, arsenic and tin determination used in proficiency resting. J Anal Atomic Spectrom. 2001;16(9):1101-6.

24. Olukanni DO, Adebiyi SA. Assessment of Vehicular Pollution of Road Side Soils in Ota Metropolis, Ogun State, Nigeria. Int J Civ Environ Eng. 2012;12(4):40-6.

25. Tangahu BV, Abdullah SRS, Basri H, Idris M, Anuar N, Mukhlisin M. A Review on Heavy Metals (As, $\mathrm{Pb}$, and $\mathrm{Hg}$ ) Uptake by Plants through Phytoremediation. Int J Chem Eng. 2011;2011:31. pages Article ID 939161, doi:10.1155/2011/939161.

26. Cho-Ruk K, Kurukote J, Supprung P, Vetayasuporn S. Perennial plants in the phytoremediation of leadcontaminated soils. Biotechnology. 2006;5(1):1-4.

27. Adamu $\mathrm{Cl}$, Nganje TN. Heavy metal contamination of surface soil in relationship to land use patterns: A case study of Benue State, Nigeria. Mater Sci Appl. 2010;103:127-34.

\section{GRAPHICAL ABSTRACT}

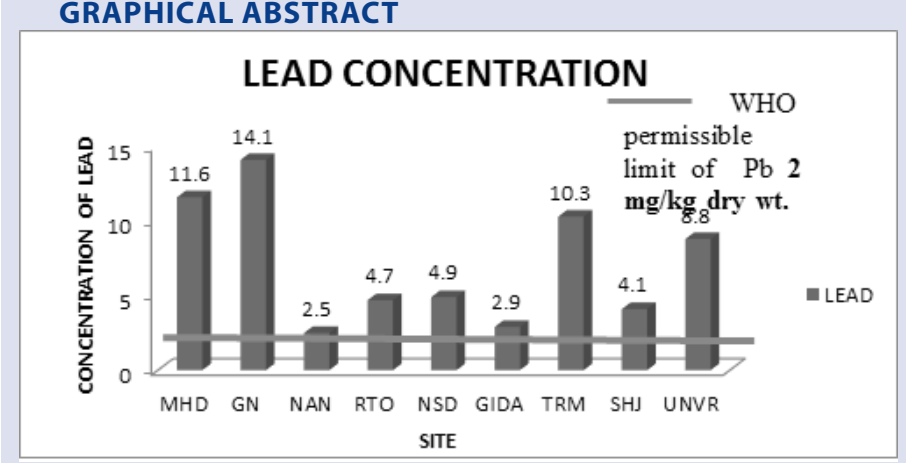

\section{SUMMARY}

- The concentration of heavy metals in the tree leaves dependent on the position of tree in the city.

- If higher traffic density occurs, the accumulation of lead in leaves was also high.

- The level of the lead in leaves of Ficus religiosa was much higher than the limits recommended by World Health Organization (WHO).

\section{ABOUT AUTHORS}

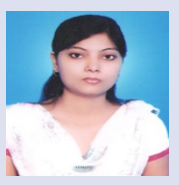

Pooja Agrahari: Post Doctoral fellow of Malacology Laboratory, Department of Zoology, DDU Gorakhpur University, Gorakhpur, UP, India. She completed her PG from DDU Gorakhpur University, Gorakhpur and enrolled for her doctorate studied under the supervision of Prof. Dinesh Kumar Singh. She completed her Ph.d in 2013 and joined UGC Post doctoral fellowship (UGC, New Delhi). She has published 8 papers in an international reputed journals having good impact factor. 

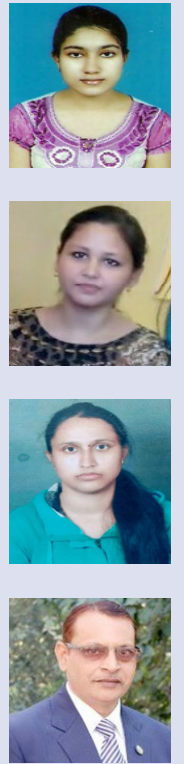

Supriya Rai: She completed her UG from St. Andrew's Degree College, Gorakhpur and PG from DDU Gorakhpur University, Gorakhpur in 2016 with environmental science. This paper is a part of their M.Sc project work.

Dr. Vinay Kumar Singh: Assistant Professor stage-III, Department of Zoology, DDU Gorakhpur University, Go $\neg$ rakhpur, UP, India has university teaching and research experiences of more than 20 years. Current research in $\rightarrow$ terests are isolation, characterization and biological evaluation of natural products and pest control, vectorborne diseases. He has published 111 research papers, 10 review articles in 65 leading International Journals of repute with high impact factors. Dr. Singh has produced 11 Ph.D. and successfully conducted 01-research projects. Dr. Singh publications have 799 citations all over world having $16 \mathrm{H}$-index and $23 \mathrm{i}-10$ index. Dr Singh is serving as Editor-in-Chief of research J of Parasitology, USA. Dr. Singh was nominated as member of University Court (JNU) by Hon'ble President of India.

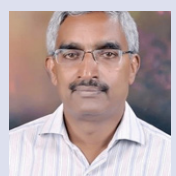

Professor D. K. Singh: Malacology Laboratory, Department of Zoology, D.D.U. Gorakhpur University, Gorakhpur, UP, India has university teaching and research experiences of more than 32 years. Current research interests are toxicology and molluscan physiology. He has published 182 research papers, 14 review articles in 75 lead-ing International Journals of repute with high impact factors. Dr. Singh publications have 3019 citations all over world having $28 \mathrm{H}$-index and $87 \mathrm{i}-10$ index Prof Singh has produced $26 \mathrm{Ph}$.D. and successfully conducted 15 research projects.

Cite this article: Agrahari P, Richa, Swati K, Rai S, Singh VK, Singh DK. Ficus religiosa Tree Leaves as Bioindicators of Heavy Metals in Gorakhpur City, Uttar Pradesh, India. Pharmacog J. 2018;10(3):416-20. 